\title{
Public Sector Transformation in the Digital Age: Obstacles and Challenges for the Government of Indonesia
}

\author{
Putri Hening ${ }^{1}$, Gozali Harda Kumara ${ }^{2}$ \\ ${ }^{1}$ National Institute of Public Administration Republic of Indonesia/ Alumni of Departement of Public \\ Admionistration University of Indonesia (email: putriihening@gmail.com), ${ }^{2}$ Village and Rural Area \\ Empowerment Agency (email: ghk@gozalikumara.com)
}

\begin{abstract}
The world has now entered the digital era. Rapid technological developments spur the transformation from the manual era to the digital era. A series of trends in this era are present such as high-level usage of the internet, the birth of social networks, the development of various applications, and fast amount of information dissemination. This trend has brought a series of changes to various sector including the public sector. The presence of digital tools in this era has changed the way Indonesian government in providing public services. This era has also changed the community's approach to interact with the government through online platforms. The transformation into the digital era also influences the process of drafting public policies, from the agenda settings, policy formulation, implementation, until evaluation. Privacy and data security issues are also present in this era. This paper analyzes how the digital era has transformed the public sector in Indonesia and the obstacles and challenges faced by the Indonesian government. This paper will also provide recommendations to overcome these obstacles and challenges. This research is conducted by using qualitative and quantitative method. In analyzing data, researcher do three simultaneously activities based on Miles and Huberman model.
\end{abstract}

\section{Introduction}

In the digital era, technology develops rapidly. Technology, such as the internet, has changed human working manner pattern in all sectors. Starting from manual era, when people used their own muscles or human-powered tools for almost everything - agriculture, construction, transportation and defense (or aggression). Then it was transformed into mechanical era when powered machines were used to augment people's physical capabilities such as for manufacturing and construction, until finally turned into digital era which is when information technologies are used to collect, store, control, manipulate and distribute the information associated with all forms of work (and play) (Sheppard, 2013). The rapid development of technology and information brings us to new era which is era with high level of technology usage, especially internet. U.N. Data per January 2019 mentioned that from the total population of 7,6 billion, the total number of internet users are 4.3 billion as seen in the picture below 
Picture I.1.

Digital Around The World

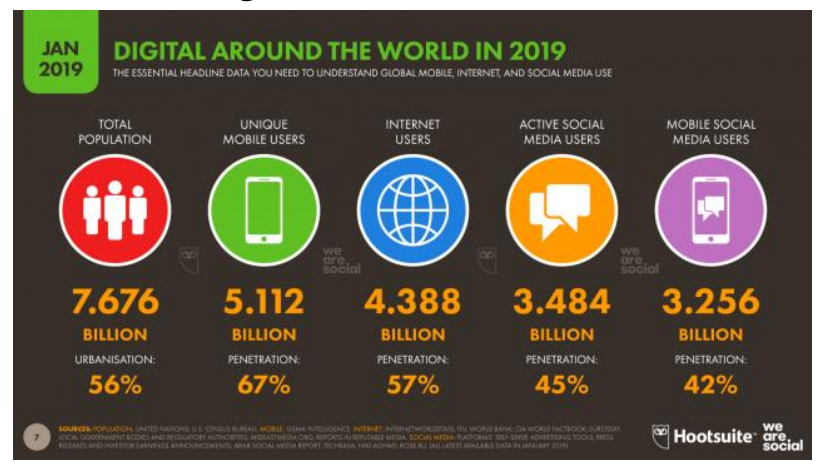

Source: United Nations, 2019

In the picture above, it can be seen the level of internet usage accompanied by the level of social media usage is quite high.

The high level of internet and social media usage is pushed both by technology developers so that various technology development companies have produced various online platforms. Presently, the level of use of various online platforms is quite active, in 1 minute, each online platform has a level of usage activity that is not small, this can be seen as follows:

Table I.1.

Activites of Online Plartforms in 1 (one) Minute

\begin{tabular}{|l|l|}
\hline Online Platforms & Activities in 1 (one) minute \\
\hline Facebook & 1 Million Logging in \\
\hline Google & 3.8 Million Search Queries \\
\hline Massage & 18.01 Million Texts sent \\
\hline Youtube & 4.5 Million Videos Viewed \\
\hline Play Store \& App Store & 390.030 Apps Downloaded \\
\hline Instagram & 347.222 Scrolling Instagram \\
\hline Twitter & 87.500 people tweeting \\
\hline Email & 188 Million email sent \\
\hline $\begin{array}{l}\text { Whatsapp \& FB } \\
\text { Messanger }\end{array}$ & 41.6 Million Messages sent \\
\hline etc. & \\
\hline
\end{tabular}

Source: 1 (one) Minute Report, 2019 
From the table above, it can be seen that in one minute, people in the world are actively use various online platforms. People use any portal and online applications for various purposes.

One of the goals of using the online platform is as a media to connect the public to the government (Citizen-Government Relationship). Online Platform is considered to be able to facilitate two-way communication between the society and the government. The society is also possible to use online platforms such as change.org or twitter to bring up issues to government. Society can criticize or support all regulations issued by Government through various online platform channel so that it can give domino effect by influence other online platform users. The internet with all its openness has stimulated various parties to express their opinions (free speech). Especially for minorities, online platforms can be a medium for them to bring up their aspirations.

Online platforms can become one voice that is considered in the process of policy making. Not only online mass media, but also social media such as Twitter and Youtube. For example, the European society actively participates in controlling public policy through various online platforms, such as the data below:

\section{Picture I.2.}

Eurupean Adults Interested in Using The Internet to Do The Following

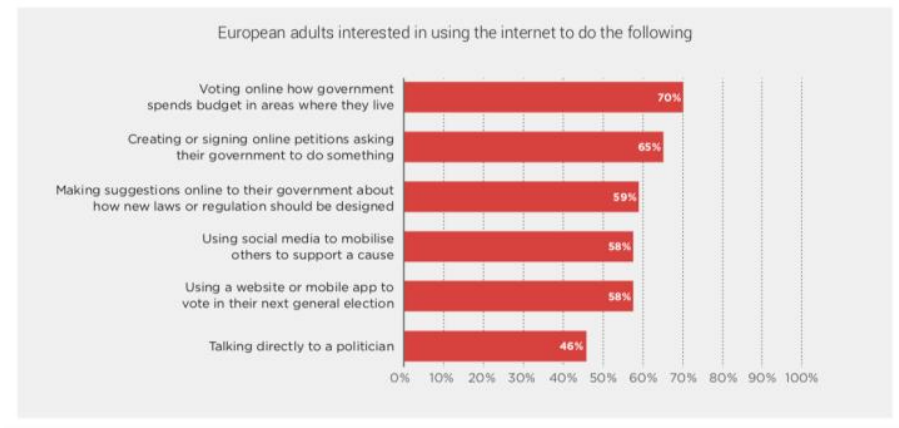

Source: Digital 2019 Reports, 2019

From the data above, it can be seen that most of the European people utilize various online platform for citizen-government relationship purpose. For 70\% European society utilize online platform in the form of online voting to determine how the government spends budget in areas where they live, then $65 \%$ of European society utilize online petition to ask government to do something, 59\% European society making suggestion online to 
their government to do something, 58\% using social media to mobilize others to support a cause $58 \%$ using a website or mobile app to vote in their next general election, and $48 \%$ European society uses online platform to talk directly to a politician.

In Indonesia, the society has also begun to use online platforms to connect with the Government. Indonesian people have begun to use change.org and Twitter to voice their aspirations to the Government. Then, use the online platform for direct criticism of public services, according to the data LIPI (2018), 7,6\% young voters in Indonesia deliver their appreciation and critics to Government through social media. Furthermore, specifically the government also provides LAPOR! as an online platform so that the public can make complaints online based on public services. Indonesian people also utilize online platforms to get many informations related to government administration.

LIPI (2018) stated that 60,6\% first Indonesian voters access political news through the internet. Online platform has changed the way people deal with government. The online platform has broken down the barrier between society and government so that people can more easily communicate with the government. This has implications for increasing public expectations of government responsiveness. The government is demanded to provide services that are faster, more precise, and transparent. So, in this digital era, the government is required to transform into a government that can utilize technology to provide maximum services to the public.

\section{Methods}

This paper analyses how the government as a public sector is transforming in the digital age. This research is conducted by using qualitative and quantitative method. In analyzing data, researcher do three simultaneously activities based on Miles and Huberman model; data reduction, data display, and conclusion drawing.

\section{Result \& Discussion}

To adapt to a series of trends that are present in the digital era, the government as a public sector is required to conduct transformation in all aspects, both in the delivery of services and in the process of formulating policies. In welcoming this digital era, there have 
been several transformations that have been conducted and can also be conducted by the Government of Indonesia with more leverage, including "Being digital”.

"Being Digital" can be interpreted as digitalized the government/ digitalization of public sector. "Being Digital" includes 2 (two) aspects which are digital tools and digital mindset. In the digital tool's aspect, the government can utilize various applications (digital tools) in the process of providing government services, from planning to evaluation. In Indonesia, various layers of government from the central to the regions already use information systems to provide services to the society. For example, as of July 2019, amounted 6537 Village Governments in Indonesia had utilized the Village Information System (SiDeka) to serve the administration of their citizens. In addition, the central and regional government also provides various information on their websites so that the public can access them, this is a form of information service.

Not only in the provision of services, Digital Tools is also utilized by the regulation maker in designing regulation. Digital Tools is also used to see the point of society preference. The use of Digital Tools in designing regulation is conducted to: (1) More Timely, allows policy makers to collect feedback from the society in real time and how an issue or program impacts the society, (2) More Data-Driven, enables policy makers to get new data quickly as information in the decision making process, (3) more inclusive, involving the society, the private sector, and stakeholders in the decision making process, and (4) More User-Focused, allows regulation makers to quickly test stakeholders related to which policies are appropriate.

Furthermore, "being digital" is not only about Digital Tools, but also about Digital Mindset. This means that the government does not only automate or digitize what the government does, but furthermore, it means about how the government thinks and deal with digital mindsets. Digital mindset is not only able to understand and use digital tools but also be able to rethink business models, stakeholder relations, stakeholder management, and organizational culture, so these things can be adapted to digital development.

The next transformation is "24/7 Government". With 24/7 Government, government can service society for 24 hours non-stop with the assistance of technology in certain services. For example, giving information service, society can access information needed. The information can be accessed anytime in 24 hours 7 days without requirement to wait the 
office open. Direct service registration can also be conducted online 24/7, for example the online passport registration service launched by the Directorate General of Immigration, Ministry of Law and Justice. With the help of ICT, public services can be on standby 24/7 to present the role of government in the society.

The next transformation is citizen-centered organizational performance. In the digital era where anything is transparent and there is no gap among society, government organization performance must be based on society interest. There are 5 (five) manner so that every government decision is based on society interests (Suarez, Abdallah, 2019) which are; (1) Role-Modeling From the Top, which is the presence of leaders whose words and actions reflect leadership that focuses on the interests of the society, (2) citizen-engagement channels, which is improving society and government relations by not only utilizing digital channels but also maintaining how society and the government can be directly meet, (3) citizen analytics, which uses big data analysis to see society preferences, (4) outcome-based measurement, which stipulates that results must be measurable, and (5) motivational levers, that is emphasis motivation to behave as "citizen-centered manner" to all entity of public sector workers.

In addition, in this digital era, government as public sector also needs to be transformed to user friendly and inclusive government. Digital principles illustrated that digital based-public services must be provided for all people, not only for people who understand technically digital. This means that all levels of society must be able to use and access digital-based public services. Digital service display must be easy to use and can be used by all groups of people in an inclusive manner. According to Data of Bappenas (2018), 15 percent of Indonesia's population are people with disabilities. In 2018, the Ministry of Communication and Information encourages all local governments to provide facilities to help people with disabilities who have special needs, one of which is by utilizing technology such as the provision of audio-visual information media in public transportation facilities. ICT can be utilized by building various facilities supporting disability services.

Beside ensure that the service given is service which is user-friendly and inclusive. Next, in this digital age the government is also required to strike a balance between innovation and regulation. The Digital Era triggers the development of various innovations, 
especially those based on digital, but the government must ensure that the innovations developed are balanced with regulations that can accommodate these innovations.

For example, the innovation that occurred in the digital era is the birth of online transportation. In 2018, Indonesia has 2 big companies that are now dominating the online transportation market share, those are Grab and Gojek. Gojek now has 1 million drivers in Indonesia while Grab has 2 million drivers in Southeast Asia (bisnis.tempo.co, 2018). The online transportation company fleet is far greater than Indonesian largest taxi company, Blue Bird Group, with 22,000 fleets (viva.co.id, 2018). In September 2018, the companies are not yet legally regarded as transportation companies. This results in Gojek and grab regardless of their rights and obligations as a transportation company. The statis of "transportation company" in gojek and grab companies is not yet atched is causes the two companies do not need to comply with labor rules, tax rules, and safety rules in the provision of transportation. These conditions bring benefits for companies but harm the governmen, conventional transportation companies, and employees, especially drivers. But, when compared with countries in Europe, this has been anticipated through a decision of European Court of Justice in 2017 which decide that uber (Transportasi Online multinasional) is an online transportation, and must run regulation like other taxis operators. (www.reuters.com, 2017). This indicates that there is transformation from conventional to digital, must be followed with outward looking and future setting regulation. The government must be responsive and give response quickly to any changes that occur in this digital era by making regulatory arrangements. Regulatory reform is not only limited to reforming regulations, but the Government of Indonesia must also welcome the digital era by issuing a series of appropriate policies.

Then, transformation is also conducted in partnership era. Government can build disruptive public-private partnership. Partnership intended is not about who to get anything (what we got VS what they get), but related to what contributions can be made in solving problems together. Each party contributes in solving joint problems. For example, government collaboration with NGOs, academics, and other parties to solve a problem. The digital age allows collaboration meetings to be conducted online between countries. 
The next transformation in public sector that is quite significant is the use of big data in the policy making process, in other words making decision enabled by big data. The government can not only use big data, but the government can also use online platforms in the process of policy making. The following is the use of big data and online platforms at each stage of the policy making process:

Table III.1.

Mapping Table of Big Data and Online Platforms Use at Each Stage of the Policy Stage

\begin{tabular}{|l|l|}
\hline Policy Stage & Utilization of Big Data \\
\hline Agenda Setting & $\begin{array}{l}\text { The government collecting data and information, one of them is from } \\
\text { social platforms (online platforms) that have a high level of participation } \\
\text { and also from Big Data, data and information to early related issues that } \\
\text { are happening in the society early and produce relevant agenda points. } \\
\text { Through online platforms and Big Data, the Government can identify the } \\
\text { policy preferences desired by the society which will then be considered in } \\
\text { setting the policy agenda } \\
\text { - ICT can be utilized by policy maker for sentiment mining/ sentiment analysis } \\
\text { to inform about trend of politics discussion this time and related to public } \\
\text { opinion }\end{array}$ \\
\hline Policy Formulation & $\begin{array}{l}\text { In the stage of Policy Formulation, Big Data can contribute in the making of } \\
\text { evidence-based policy with advanced predictive analytic methodology and } \\
\text { scenario techniques. }\end{array}$ \\
\hline Implementation & $\begin{array}{l}\text { The implementation of policy can be influenced by Big Data in two } \\
\text { manners: (1) The ability to determine the problem zone can become a } \\
\text { manner to determine the intensity of policy implementation (how far the } \\
\text { policy is implemented), and (2) The implementation of the new policy } \\
\text { will also immediately produce new data, which then can be used to } \\
\text { evaluate the effectiveness of the policy and improve the implementation } \\
\text { process in the future by identifying problems. } \\
\text { - Several other information sources is focused on implementation of policy } \\
\text { to be able to increased its accuracy by Big Data. }\end{array}$ \\
\hline Policy Evaluation & $\begin{array}{l}\text { Evaluation by utilizing complaint, critics and suggestion from society } \\
\text { through Online Reports } \\
\text { Evaluation is not happen in the last process but continuously, open } \\
\text { permanent possibility for handling, reassessment, and consideration. }\end{array}$ \\
\hline
\end{tabular}

From the table above it can be seen that big data and online platform can be utilized in each policy making stage. But unfortunately the use of big data by the Government of Indonesia has not been maximized. Currently the Government of Indonesia is using big data to take inflation control policies in several cities. Big Data is believed to be the key to building an accelerated economy. But it is difficult for the Government of Indonesia to expand the use of big data in the process of policy making because of internet network 
problems in Indonesia. Internet penetration in Indonesia is only around 51\%, far below Malaysia $71 \%$ and Thailand $67 \%$. In fact, if obstacles in the use of digital technology can be overcome, it is estimated that economic digitalization can provide an added value of US \$ 150 billion to Indonesian GDP in 2025 or around $10 \%$ of GDP.

In conducting transformation in digital era, Government of Indonesia must also pay attention to privacy issue and data security. The issue of privacy becomes dilemmatic because the Government must protect privacy but must also promote transparency, two things that are contradictory but must go hand in hand. In this case, data protection laws are very important. In Indonesia, the current regulation on protecting personal data is only regulated in Minister of Communication and Information Minister Regulation (Permenkominfo) Number 20 of 2016 concerning Protection of Personal Data in Electronic Systems. The Ministry of Communication and Information and the House of Representatives (DPR) have discussed the Draft Personal Data Protection Act (PDP Bill) which regulates about definition, types, ownership rights, processing, delivery, authorized institutions that regulate personal data to sanctions. However, until now the PDP Bill has not yet been passed. Another problem is that the Indonesian government's information system is considered to be weak in security. Based on information from the Ministry of Communication and Information Technology (Kominfo) in 2012, as much as 50 percent of official websites with the domain go.id have been hacked by hackers. In 2019, there are still government websites that can be hacked by hackers such as KPAI, Ministry of Home Affairs, Madiun Regency Government, etc. The government must ensure that the government is able to secure data privacy and security in this digital era.

\section{Challenges \& Obstacles of Government of Indonesian in Digital Era}

Several challenges and obstacles are faced by Government of Indonesia in conducting transformation in this digital era. One of the obstacles is the level of technological literacy of public servants is still low. From total 4,5 Of the Million Civil Servants in Indonesia, only $20 \%$ of them understand information and communication technology (ICT) (www.inet.detik.com, 2016). As of 2019, the Indonesian government claims to have 572,000 technology-literate employees (kompas.com, 2019), but when 
compared with the number of civil servants per 2019 of 4.3 million people, it means that only technology-literate civil servants 13,30\%.

The next problem is infrastructure problems of ICT in Indonesia which is not yet adequate. According to data from the Ministry of Communication and Information in 2016, the average internet speed in various regions of Indonesia is very old, with an average internet speed of $0.4 \mathrm{Mbps}$ in Maluku-Papua compared to $7 \mathrm{Mbps}$ in Jakarta as shown below:

Picture III.1.

The average speed of Internet in Indonesia

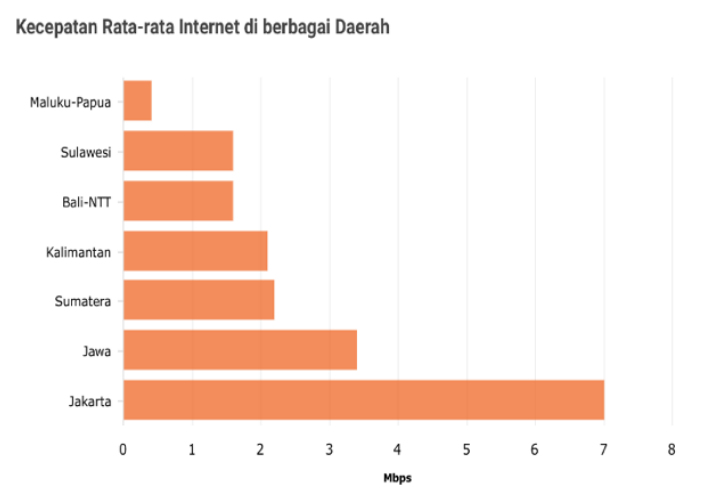

Source: Kemenkominfo, 2016

Condition of internet quality that is not evenly distributed becomes obstacles for government effort to conduct transformation of digital service. Internet discrepancy in areas of Indonesia becomes big work to do for Government of Indonesia. Project of Palapa Ring 2020 becomes one of the steps taken by the Government of Indonesia to reach remote areas so as to reduce existing disparities. Palapa Ring is a telecommunications infrastructure project in the form of the construction of optical fiber throughout Indonesia along 36,000 kilometers. The project consists of seven small optical fiber circles that will reach 440 cities / districts throughout Indonesia (Kominfo, 2018).

Until now, palapa ring project is still in processing stage. There are some obstacles in this project, one of which is obstacles that come from local government regulations. For example when the development of West Palapa Ring (PRB) in several villages in 3 anambas islands experiences obstacles because of Anambas Islands District Regulations governing the establishment of Base Transceiver Station (BTS) at height above 52 meters are required to 
use an Environmental Impact Analysis so that this slows down the construction of BTS for DRR projects in the Anambas islands, even though this DRR project is very important given the telecommunications conditions in the Ambas Islands which are still far behind from other regions.

The Regional Government must start to pay attention to immediately review the rules that actually slow down the central government program for the Palapa Ring project. The development project for the acceleration of telecommunications networks covering remote areas must be supported by collaboration between the central and regional governments. If the Palapa Ring project is completed, a high-capacity, high-quality, secure and inexpensive internet and communication network will be born so that it can support government to be reformed in the digital age, both in service and in the process of policy making.

\section{Conclusion}

Trends that occur in this digital era have brought a trigger that requires government to conduct transformation, both in the process of formulating policies and providing services. Until now, the government has and will conduct various series of transformations, starting from being digital, 24/7 government, citizen-centered organizational performance, inclusiveness, balancing innovation-regulation, disruptive public-private partnership and the utilization of big data in the process of policy making. In transformation process of digital era governance, the government faces a series of obstacles such as the low level of technological literacy of civil servants in Indonesia, inadequate infrastructure, and regulations that do not yet accommodate the digital era.

What the government can try to do is to improve the digital literacy ability of civil servants through a series of ICT training. The government is required to ensure that more than $50 \%$ of civil servants are able to master ICT. Then, the Government must also improve ICT infrastructure from Sabang to Merauke. Equitable internet network has to be finished. The central and regional government must ensure that the existing policies must support the internet network equity program. All The efforts were created to realize the governance. 


\section{References}

\section{Books}

Chen, Yu-Che, and Tsui-Chuan Hsieh. 2014. “Big Data for Digital Government: Opportunities, Challenges, and Strategies." International Journal of Public Administration in the Digital Age

Suraez, David. Abdallah, Ehsan. Public Sector Readiness in The Digital Age of Disruption. PWC

\section{Regulation}

Peraturan Menkominfo No. 20 Tahun 2016 tentang Perlindungan Data Pribadi Dalam Sistem Elektronik

\section{Website}

Desjardins, Jeff. 2019. What Happens in an Internet Minute in 2019? Internet in 1 (one) Minute. https://www.visualcapitalist.com/what-happens-in-an-internet-minute-in$2019 /$

Don, Sheppard. 2013. Thought on The Digital Era. https://www.itworldcanada.com/blog/thoughts-on-the-digital-era/85482

Floretti, Julia. 2017. "Uber dealt blow after EU court classifies it as transport service". https://www.reuters.com/article/us-uber-court/uber-dealt-blow-after-eu-courtclassifies-it-as-transport-service-idUSKBN1EE0W3

Hootsuite: We Are Social. 2019. Global Digital Report 2019. https://wearesocial.com/blog/2019/01/digital-2019-global-internet-use-accelerates

Kemenkominfo. $2018 . \quad$ Kota $\quad$ Ramah Disabiltas. https://kominfo.go.id/content/detail/13685/kota-ramah-disabilitas-fasilitas-apa-sajayang-mesti-tersedia/0/sorotan_media

Kemenkominfo. 2018. 2018. "Sekilas Palapa Ring". https://kominfo.go.id/content/detail/3298/sekilas-palapa-ring/0/palapa_ring Diakses pada tanggal 19 September 2018

Paskalis, Yohanes. 2018. "Intip Peta Kekuatan Armada Gojek Versus Grab". https://bisnis.tempo.co/read/1073905/intip-peta-kekuatan-armada-go-jek-versusgrab/full\&view=ok Diakses pada tanggal 22 September 2018 
Rahman, Adi Fida. 2016. Dari 4,5 Juta PNS, Cuma 20\% yang Melek Teknologi. https://inet.detik.com/law-and-policy/d-3374933/dari-45-juta-pns-cuma-20-yangmelek-teknologi

Setyowati. 2018. LIPI: 60\% Anak Muda Akses Berita Politik Lewat Media Sosial". https://katadata.co.id/berita/2018/07/18/lipi-60-anak-muda-akses-berita-politik-lewatmedia-sosial

Tim Penulis Viva. 2018. "Daya Saing Naik, Bluebird Tambah 4000 armada tahun ini." https:/www.viva.co.id/berita/bisnis/1039686-daya-saing-naik-blue-bird-tambah-4-000armada-tahun-ini 